Article

\title{
Implementation of an Advance Care Planning Inventory and Its Possible Effect on Quality of Dying: A Nationwide Cross-Sectional Study in Group Homes for Persons with Dementia in Japan
}

\author{
Seira Takada ${ }^{1,2, *(\mathbb{D})}$, Yasuko Ogata ${ }^{1}$, Yoshie Yumoto $^{1} \mathbb{D}$ and Masaomi Ikeda ${ }^{3} \mathbb{D}$ \\ 1 Department of Gerontological Nursing and Healthcare Systems Management, Graduate School of Health \\ Care Sciences, Tokyo Medical and Dental University (TMDU), Tokyo 113-8510, Japan; \\ yogata.gh@tmd.ac.jp (Y.O.); yumoto.gh@tmd.ac.jp (Y.Y.) \\ 2 Department of Gerontological Nursing, Faculty of Nursing, Toho University, Tokyo 143-0015, Japan \\ 3 Department of Oral Prosthetic Engineering, Graduate School of Medical and Dental Sciences, Tokyo Medical \\ and Dental University (TMDU), Tokyo 113-8510, Japan; ikeda.csoe@tmd.ac.jp \\ * Correspondence: ns160003@tmd.ac.jp
}

Citation: Takada, S.; Ogata, Y.; Yumoto, Y.; Ikeda, M.

Implementation of an Advance Care Planning Inventory and Its Possible Effect on Quality of Dying: A Nationwide Cross-Sectional Study in Group Homes for Persons with Dementia in Japan. Healthcare 2022, 10, 62. https://doi.org/

10.3390/healthcare10010062

Academic Editors: Tetsuya Tanioka and Michael Joseph Dino

Received: 1 December 2021

Accepted: 27 December 2021

Published: 29 December 2021

Publisher's Note: MDPI stays neutral with regard to jurisdictional claims in published maps and institutional affiliations.

Copyright: (c) 2021 by the authors. Licensee MDPI, Basel, Switzerland. This article is an open access article distributed under the terms and conditions of the Creative Commons Attribution (CC BY) license (https:// creativecommons.org/licenses/by/ $4.0 /)$.

\begin{abstract}
This study aimed to develop an inventory for advance care planning implementation for persons with dementia in group homes and to examine the association between inventory implementation and residents' quality of dying. A nationwide cross-sectional study was conducted via questionnaires mailed from 2000 group homes in Japan, selected through stratified random sampling. Participants were managers and care planners who had provided end-of-life care for recently deceased residents. The newly developed inventory was used to assess advance care planning implementation for persons with dementia, and the Quality of Dying in Long-term Care Scale was used to evaluate quality of dying. The valid response rate was $28.5 \%(n=569)$. The factor structure of the newly developed Advance Care Planning Practice Inventory and the association between its implementation and quality of dying were verified using factor analysis and internal consistency, and logistic regression, respectively. The composite score and the factor score of the newly developed inventory were significantly associated with quality of dying $(p<0.05)$. The implementation of advance care planning improves the quality of dying. These findings can be used in development of educational programs, as well as research on advance care planning for care providers.
\end{abstract}

Keywords: dementia; nursing care; advance care planning; group homes; long-term care

\section{Introduction}

The number of persons with dementia (PWD) is expected to increase worldwide as the population ages, and Japan is no exception [1,2]. As dementia symptoms progress, PWD find it difficult to express their wishes and live independently; some move into nursing and aged care facilities. Group homes for PWD are one such type of residence-a community-based service covered by long-term care insurance that started in Japan in 2000 [3]. The facility has a typical capacity of five to nine residents per unit, with a 3:1 resident-to-staff ratio during the day. Care is provided primarily by caregivers, and group homes should not be staffed with medical staff [4]. An additional end-of-life care bonus is allotted to group homes for PWD to strengthen end-of-life care [5], and more than half of the group homes for PWD provide end-of-life care in collaboration with visiting nurses and commissioned doctors. In addition, more than $60 \%$ of residents' family members wish for the residents to spend their final days in the group home, with which they are familiar [6]; this is expected to further promote end-of-life care. To improve the quality of end-of-life 
care in these facilities, the practice of advance care planning (ACP) is comparably important to the home facilities themselves [7].

ACP involves facilitating adults at any age or health stage to comprehend and share their values, goals, and preferences pertaining to future medical care [8]. Its effectiveness has been well-researched, and its implementation is recommended to improve the quality of end-of-life care $[9,10]$. ACP is preferred, in part, because it ensures that patients die where they desire; this is desirable since it not only accounts for the needs and wants of the dying patient but also reduces the psychological burden on family and staff [11-13]. However, Dixon et al. [9] suggest that ACP may be underestimated in intervention studies because of a "black box" that does not clearly show how ACP is implemented; this is an issue that needs to be resolved in quantitative studies as well. To assess the effectiveness of $\mathrm{ACP}$, it is necessary to clarify and evaluate its contents and to examine its relationship to the quality of end-of-life care.

Therefore, we developed an inventory to assess the implementation of ACP for PWD in group homes in order to clarify the structure of ACP and to examine the association between implementation of the inventory and quality of dying.

\section{Materials and Methods}

\subsection{Participants and Procedure}

In this nationwide cross-sectional study, using a publicly available database [14], 2000 facilities were randomly selected through stratified sampling by prefecture from approximately 6000 group homes for PWD that provide end-of-life care. Since the response rate tends to be low in national surveys of group homes in Japan, this number was deemed appropriate to ensure a sufficient sample size for factor analysis (4-10 times the number of variables) [15].

Data collection took place from August to September 2020. There were two types of questionnaires: one for managers and one for care planners for residents who had recently died in the facility. The questionnaires, along with return envelopes, was mailed to target facilities, and the respective managers distributed them to care planners. To increase the response rate, research assistants explained the survey outline to the managers over the phone, and two bi-weekly reminders were sent to the facilities after questionnaire distribution. The researchers conducted an online briefing for each research assistant, provided them with a manual to follow, and explained the instructions. The questionnaires were merged based on a pre-assigned identification number (ID). To ensure anonymization, the IDs were provided by a third-party agency, and the researchers were not informed of the assigned IDs. We merged the questionnaires based on IDs and the valid responses received that met the following inclusion criteria: (a) responses were received from both the manager and care planner and (b) none of the variables used in the analysis was missing.

\subsection{Measures}

\subsubsection{Demographic Characteristics}

The questionnaire included items on participants' age, sex, years of experience at the current facility, and job type. The questionnaire for managers included items about the facility's characteristics (e.g., organization, year of opening, resident capacity, and average level of long-term care required); for care planners, it included items about the deceased resident's characteristics (e.g., age, sex, length of stay, level of independence, quality of dying, and ACP Practice Inventory).

\subsubsection{ACP Practice Inventory (ACP-PI)}

This inventory indicates the ACP tasks for PWD living in group homes. The authors conducted a scoping review in 2017 following a guideline [16] to identify ACP components for older adults with dementia living in senior living facilities. We developed a list of 38 items after the review. We combined several factors to constitute the ACP-PI from the Japanese ACP guidelines [17,18], such as "Discuss end-of-life intentions with the residents 
themselves" and "Support decision making by considering the cognitive functions of residents". Items included "We talked with Mr./Ms. A about where they would like to spend the final stages of life", "We talked with Mr./Ms. A about what kind of medical treatment/care they wished for at the final stage of life", "We considered the topics of discussion regarding the final stage of Mr./Ms. A's life depending on their cognitive functioning", and others. We interviewed seven staff members working in group homes to determine the feasibility of implementing the items. Additionally, an expert panel of five experts in dementia and institutional care (e.g., Certified Nurse Specialists in gerontology and senior-citizen facility administrators) was convened to review the feasibility, necessity, and validity of each item and verify the content validity. The experts rated each item on a scale of 1-9 for validity; average score $\geq 7$ was considered appropriate [19], and 33 items were classified as appropriate. Five items (score range: 5.8-6.6) were less than 7 (range 5.8-6.6) and were grouped as "uncertain" (score range: 4-6). As these five items were classified as "uncertain" and not "inappropriate" (less than 3), they were used directly in the next survey. Based on their recommendations, all items were included, and one more item was added because it was important in decision making to make sure that the PWD understood what was being discussed. A pilot survey was conducted in 2019 in nursing homes with characteristics similar to those of group homes. However, since the response rate for this pilot survey was very low $(13 \%)$, we decided that it would be ineffective to eliminate or modify items based on the results because the low response rate could lead to the accidental deletion of some important items. Thus, the 39 items used in the pilot test were directly used in this study as draft items for the ACP-PI. Each item is rated on a 4-point Likert scale (1: "Did not implement," 2: "More or less did not implement," 3: "More or less implemented," and 4: "Implemented").

\subsubsection{Quality of Dying}

The Quality of Dying in Long-term Care (QOD-LTC) Scale, a reliable and valid instrument, comprises three factors (personhood, preparatory tasks, and closure) across 11 items [20]. It uses a 5-point Likert scale, with higher scores indicating higher quality of end-of-life care. For the sub-factors, the average score for items consisting of the factor is calculated. The overall score is then calculated as the average of the three factor scores (range: 1-5 for the sub-scale and total scores). The scale was translated into Japanese with the developer's permission. Cronbach's alpha in this study was 0.80 for all QOD-LTC items and $0.75,0.55$, and 0.63 for the three factors-personhood, preparatory tasks, and closure-respectively. Since the QOD-LTC scores were non-normally distributed, this study used a dichotomous distribution according to the median, where scores $\leq 3$ were categorized as "low group", and scores $>3$ were categorized as "high group".

\subsubsection{Covariates}

To examine the association between ACP-PI and QOD-LTC, resident- and facilityrelated variables predicted to be associated based on existing studies and empirical data were used as covariates. Resident-related variables included the resident's sex, age at death, years of residence, and functioning before death [10]. Facility-related variables included the acquisition of the end-of-life care bonus and number of full-time nurses. Life functioning before the death of PWD was assessed by the staff based on functional assessment staging, which represents the stage of functional impairment in activities of daily living due to dementia [21]. In this study, the cut-off score for severe dementia-little to no speech and requiring full assistance-was 7 , and scores $\leq 6$ indicated less than moderately severe dementia [22].

The facilities were required to meet the following requirements to receive the end-oflife bonus: 24-h nurse availability, explaining a policy for end-of-life care to the patient and/or family, providing care with the consent of the patient or their family, and having an end-of-life care system through the Plan-Do-Check-Action cycle [23]. 
2.2.5. Japanese Version of the Frommelt Attitudes toward Care of the Dying Scale, Short Version (FATCOD-B-J-S)

This instrument measures staff attitude toward dying patients (six items and two factors) [24,25]. Items 2 and 3 are reversed items, so the score is set to "subtract the score from 6." The score for each sub-factor is the sum of items [range: 3-15], and the total score is the sum of sub-factors [range: 6-30]. In this study, only care planners' responses to one of the sub-scales, "positive attitudes toward caring for dying persons," were used.

\subsection{Analysis}

After computing the descriptive statistics, the ACP-PI's validity and reliability were examined. Logistic regression analysis was then performed.

\subsubsection{Validity and Reliability of the ACP-PI}

An exploratory factor analysis (EFA) and a confirmatory factor analysis (CFA) were performed after confirming item distribution in order to identify the structure of the items in the ACP-PI. Both EFA and CFA are methods of measuring constructive validity. The first step is to conduct EFA and establish the factors of the inventory; then, CFA is used to validate the established factors. Data from the same group home were randomly divided into two datasets: $40 \%$ for EFA $(N=228)$ and $60 \%$ for CFA $(N=341)$. EFA was performed using principal axis factoring and promax rotation. Before the EFA, Bartlett's and KaiserMeyer-Olkin tests were performed. The number of factors was determined by eigenvalues $>1$, scree plots, and factor interpretability. Items with factor loadings $<0.45$ were deleted. We performed CFA using weighted least square mean and variance adjusted (WLSMV) because these are used for ordinal data. The sample size after splitting satisfied the sample size required for WLSMV $(N>300)$ [26]. The criteria for the model's goodness of fit were as follows: comparative fit index (CFI), the Tucker-Lewis index (TLI) $>0.95$, rootmean-square error of approximation (RMSEA) $<0.06$, and standardized root-mean-square residual $($ SRMR) $<0.08[27,28]$.

To test the criterion-related validity of the ACP-PI items, Spearman's correlation analysis was performed using sub-factor scores of the FATCOD-B-J-S and QOD-LTC as external criteria. The QOD-LTC sub-factor, "preparatory tasks", includes items such as "documenting treatment wishes" and "nominating a surrogate decision maker". The "advance directive" included as a component of the ACP is similar to this documentation and nominating and was expected to have a moderately positive correlation with the "preparatory tasks" of the QOD-LTC. The FATCOD-B-J-S sub-scale, "positive attitudes toward caring for dying persons", includes items such as "I feel uncomfortable talking about death with dying patients"; it was expected to have a small-to-moderate positive correlation with the ACP-PI. Cronbach's alpha coefficient was calculated to confirm the internal consistency of the ACP-PI [29].

\subsubsection{Logistic Regression Analysis}

Logistic regression analysis was performed using the simultaneous entry method, with the QOD-LTC as the dependent variable and scores on ACP-PI, facility, and resident demographic variables as the independent variables. To avoid multicollinearity, Spearman's correlation analysis was performed, and variables with a correlation coefficient $\geq 0.7$ were excluded [30]. In the analysis, the composite score and the score of each factor of the ACP-PI were used in the following models: for Model 1, only the composite score of the ACP-PI was entered; for Models 2-4, each factor of the ACP-PI was entered separately; for Model 5, all factors of the ACP-PI were included simultaneously. Other variables were used in all models. The significance level was set at $p<0.05$. SPSS Statistics Ver. 27 for Windows and Mplus ver. 8.5 for Windows were used for analysis. 


\subsection{Ethical Considerations}

The Medical Research Ethics Committee of Tokyo Medical and Dental University approved this study (approval number: M2019-064). Participants were informed in writing to respond freely to the questionnaire. The responses were anonymous, and those who consented to participate were included in the analysis.

\section{Results}

Figure 1 presents the flow chart for participants included in the study and final analysis. The valid response rate was $28.5 \%$ for both managers $(n=569)$ and care planners $(n=569)$; it was calculated by dividing the number of responses by the number of distributions $(n=2000)$ after excluding missing or incomplete responses. Using the pre-assigned IDs, we merged the responses of managers and care planners at the same facility into one set, resulting in a rate of $28.5 \%(n=569)$ valid responses for the set.

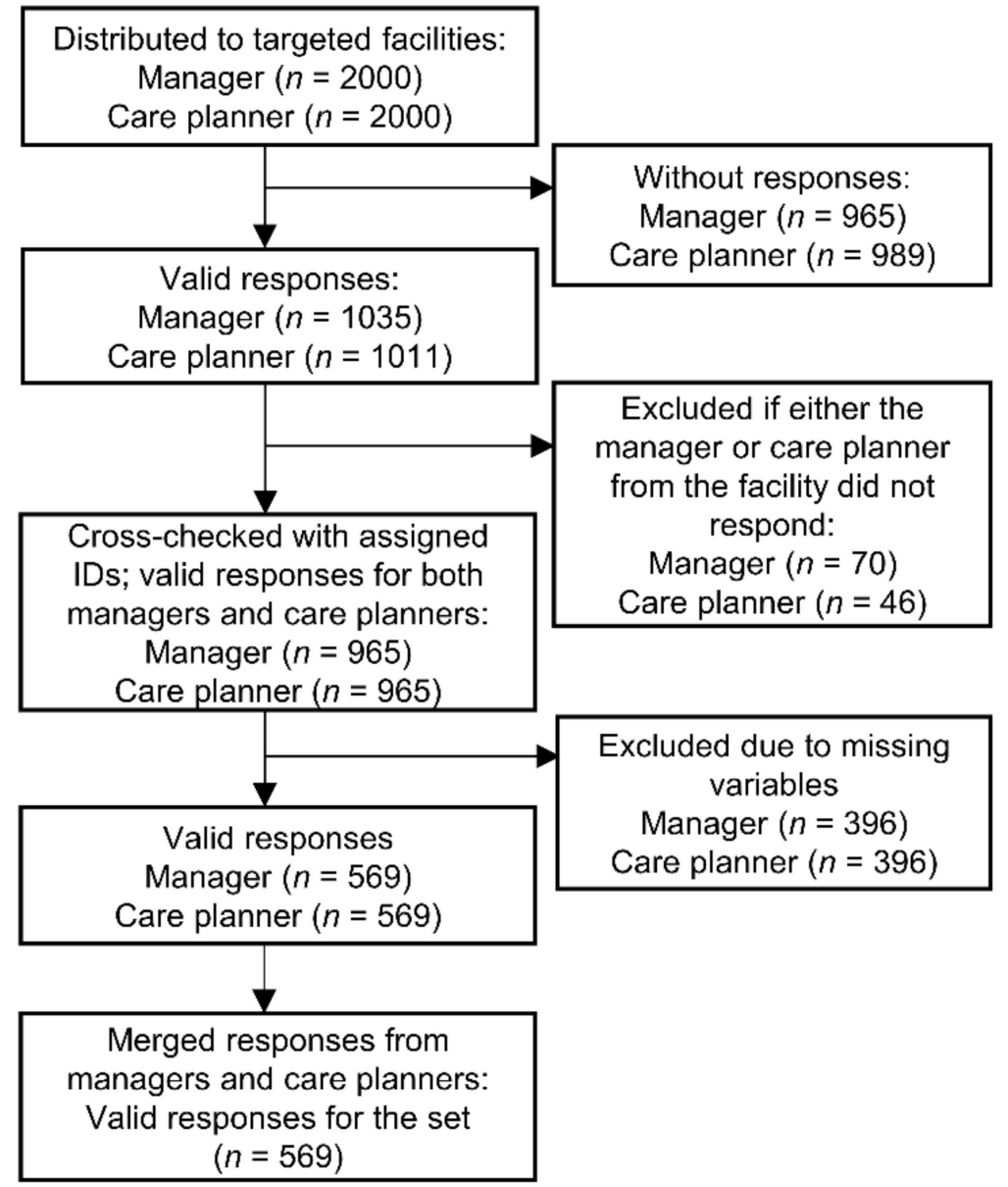

Figure 1. Flow chart of the study participants.

Table 1 presents the characteristics of the facilities, managers and care planners, and Table 2 presents those of the recently deceased residents. 
Table 1. Characteristics of the facilities, managers, and care planners $(N=569)$.

\begin{tabular}{|c|c|c|}
\hline Variables & Frequency $(\%)$ & Mean (SD) \\
\hline \multicolumn{3}{|l|}{ Facility } \\
\hline \multicolumn{3}{|l|}{ Established by } \\
\hline Social welfare corporations & $115(20.2)$ & \\
\hline Medical corporations & $103(18.1)$ & \\
\hline For-profit corporations & $300(52.7)$ & \\
\hline Other or no response & $51(9.0)$ & \\
\hline \multicolumn{3}{|l|}{ Number of units } \\
\hline 1 & $150(26.4)$ & \\
\hline 2 & $370(65.0)$ & \\
\hline 3 or more & $38(6.7)$ & \\
\hline No response & 11(1.9) & \\
\hline Year of establishment (A.D.) & & $2007.0(6.2)$ \\
\hline Number of full-time nurses & & $0.8(2.5)$ \\
\hline Number of residents & & $15.9(6.5)$ \\
\hline \multicolumn{3}{|l|}{ Managers } \\
\hline \multicolumn{3}{|l|}{ Sex } \\
\hline Male & $229(40.2)$ & \\
\hline Female & $333(58.5)$ & \\
\hline No response & $7(1.2)$ & \\
\hline \multicolumn{3}{|l|}{ Type of work ${ }^{+}$} \\
\hline Care worker & $429(75.4)$ & \\
\hline Care manager & $252(44.3)$ & \\
\hline Nurse & $40(7.0)$ & \\
\hline Age (years) & & $49.8(10.5)$ \\
\hline Experience at the facility (years) & & $9.8(5.7)$ \\
\hline Experience as a manager (years) & & $5.9(4.8)$ \\
\hline \multicolumn{3}{|l|}{ Care Planners } \\
\hline \multicolumn{3}{|l|}{ Sex } \\
\hline Male & $152(26.7)$ & \\
\hline Female & $410(72.1)$ & \\
\hline No response & $7(1.2)$ & \\
\hline \multicolumn{3}{|l|}{ Type of work ${ }^{+}$} \\
\hline Care worker & $446(78.4)$ & \\
\hline Care manager & $410(72.1)$ & \\
\hline Nurse & $32(5.6)$ & \\
\hline Age (years) & & $50.0(10.9)$ \\
\hline Experience at the facility (years) & & $8.4(5.3)$ \\
\hline \multicolumn{3}{|l|}{ FATCOD-B-J-S score } \\
\hline Total & & $23.1(2.8)$ \\
\hline Sub-scale 1 & & $11.4(1.8)$ \\
\hline Sub-scale 2 & & $11.7(2.0)$ \\
\hline
\end{tabular}


Table 2. Characteristics of the recently deceased residents $(N=569)$.

\begin{tabular}{|c|c|c|}
\hline Variables & Frequency $(\%)$ & Mean (SD) \\
\hline \multicolumn{3}{|l|}{ Sex } \\
\hline Male & $124(21.8)$ & \\
\hline Female & $445(78.2)$ & \\
\hline FAST level at the time of death & & $6.4(1.1)$ \\
\hline 6 or less & $224(39.4)$ & \\
\hline 7 & $345(60.6)$ & \\
\hline \multicolumn{3}{|l|}{ Presence of end-of-life bonus } \\
\hline Yes & $359(63.1)$ & \\
\hline Length of stay in the facility (years) & & $4.6(3.8)$ \\
\hline Age at the time of death (years) & & $91.4(6.4)$ \\
\hline \multicolumn{3}{|l|}{ QOD-LTC score } \\
\hline Composite score & & $3.3(0.7)$ \\
\hline Sub-scale 1 & & $3.9(0.6)$ \\
\hline Sub-scale 2 & & $3.3(0.8)$ \\
\hline Sub-scale 3 & & $2.7(1.2)$ \\
\hline \multicolumn{3}{|l|}{ QOD-LTC score } \\
\hline High & $354(62.2)$ & \\
\hline
\end{tabular}

\subsection{Validity and Reliability of the ACP-PI}

Items with skewed distributions were eliminated (Table 3), resulting in 22 items. In the EFA, four items were excluded due to low factor loadings and commonality, resulting in 18 items and 3 factors: "provision of information and conversation with the resident to encourage them to express their end-of-life wishes", "preparations in case the resident becomes unable to express their own end-of-life wishes", and "devising ways to encourage the resident to express their wishes with consideration for their dementia". Table 4 shows the results of the EFA and the Cronbach's alpha coefficients.

After establishing the factor structure through EFA, CFA was conducted to confirm the factor structure. The CFA results for the initial model were: RMSEA $=0.101(90 \%$ confidence interval (CI) 0.093-0.109), CFI $=0.980, \mathrm{TLI}=0.977$, and SRMR $=0.041$. The paths of the error correlations based on the modification indices were added, and the results were: RMSEA $=0.069(90 \%$ CI 0.060-0.078), CFI $=0.991$, TLI $=0.989$, and SRMR $=0.033$. Since the number of items differed among the factors, each factor's score was calculated as the sum of the item scores for each factor divided by the number of items in that factor. The composite score for items of the ACP-PI was calculated by summing each factor's scores and dividing by the number of factors. The composite scores and the scores for each factor are also shown in Table 4. The final version of the ACP-PI is shown in the Table 5. 
Table 3. Items with ceiling effects $(N=569)$.

\begin{tabular}{|c|c|c|c|c|c|c|}
\hline \multirow[b]{2}{*}{ No. } & \multirow[b]{2}{*}{ Items } & \multicolumn{4}{|c|}{ Frequency (\%) } & \multirow[b]{2}{*}{$\begin{array}{l}\text { Mean } \\
\text { (SD) }\end{array}$} \\
\hline & & $\begin{array}{l}\text { Did Not } \\
\text { Implement }\end{array}$ & $\begin{array}{l}\text { More or Less } \\
\text { Did Not } \\
\text { Implement }\end{array}$ & $\begin{array}{l}\text { More or Less } \\
\text { Implemented }\end{array}$ & Implemented & \\
\hline 23 & $\begin{array}{l}\text { We asked Mr./Ms. A's family members and } \\
\text { other relevant parties about what Mr./Ms. } \\
\text { wished regarding the final stage of life. } \\
\text { We talked with A's family members about }\end{array}$ & $16(2.8)$ & $6(1.1)$ & $80(14.1)$ & $467(82.1)$ & $3.8(0.6)$ \\
\hline 24 & $\begin{array}{l}\text { Mr./Ms. A's medical treatment/care options } \\
\text { for the final stage of life. }\end{array}$ & $16(2.8)$ & $2(0.4)$ & $60(10.5)$ & $491(86.3)$ & $3.8(0.6)$ \\
\hline 25 & $\begin{array}{l}\text { We talked with Mr./Ms. A's family members or } \\
\text { other relevant parties about relief and comfort } \\
\text { care for distressing symptoms (e.g., } \\
\text { breathlessness or discomfort from being unable } \\
\text { to move) at the final stage of life. }\end{array}$ & $17(3.0)$ & $9(1.6)$ & 72 (12.7) & $472(83.0)$ & $3.8(0.6)$ \\
\hline 26 & $\begin{array}{l}\text { We facilitated and supported Mr./Ms. A's } \\
\text { discussions with their family members so that } \\
\text { they could all reach a consensus concerning the } \\
\text { policies and procedures regarding the final } \\
\text { stage of life. }\end{array}$ & $26(4.6)$ & $29(5.1)$ & 112 (19.7) & 402 (70.7) & $3.6(0.8)$ \\
\hline 27 & $\begin{array}{l}\text { In cases where family members or other } \\
\text { relevant parties requested, staff members } \\
\text { always accepted calls for consultation } \\
\text { regarding the final stage of Mr./Ms. A's life. }\end{array}$ & $13(2.3)$ & $4(0.7)$ & $107(18.8)$ & 445 (78.2) & $3.7(0.6)$ \\
\hline 28 & $\begin{array}{l}\text { After discussing Mr./Ms. A's medical } \\
\text { treatment/care policies with both family and } \\
\text { staff members, we documented the details in } \\
\text { Mr./Ms. A's records. }\end{array}$ & $16(2.8)$ & $16(2.8)$ & 85 (14.9) & $452(79.4)$ & $3.7(0.7)$ \\
\hline 29 & $\begin{array}{l}\text { We asked family members and relevant parties } \\
\text { whether or not there were any changes in their } \\
\text { wishes regarding Mr./Ms. A's medical } \\
\text { treatment/care, as needed. }\end{array}$ & $16(2.8)$ & $22(3.9)$ & 109 (19.2) & $422(74.2)$ & $3.7(0.7)$ \\
\hline 31 & $\begin{array}{l}\text { We recorded wishes Mr./Ms. A had in relation } \\
\text { to the kind of medical treatment/care. }\end{array}$ & $55(9.7)$ & $53(9.3)$ & $127(22.3)$ & 334 (58.7) & $3.3(1.0)$ \\
\hline 32 & $\begin{array}{l}\text { Information about Mr./Ms. A, even if it was } \\
\text { not medical treatment/care-related, was kept } \\
\text { in the records. }\end{array}$ & $7(1.2)$ & $17(3.0)$ & $139(24.4)$ & $406(71.4)$ & $3.7(0.6)$ \\
\hline 33 & $\begin{array}{l}\text { The medical treatment/care policies for the } \\
\text { final stage of Mr./Ms. A's life were discussed } \\
\text { and decided by the team at the facility. }\end{array}$ & $8(1.4)$ & $22(3.9)$ & $139(24.4)$ & $400(70.3)$ & $3.6(0.6)$ \\
\hline 34 & $\begin{array}{l}\text { We shared Mr./Ms. A's wishes regarding } \\
\text { medical treatment/care with the } \\
\text { relevant doctors. }\end{array}$ & $14(2.5)$ & $11(1.9)$ & $112(19.7)$ & $432(75.9)$ & $3.7(0.6)$ \\
\hline 35 & $\begin{array}{l}\text { We shared Mr./Ms. A's wishes regarding their } \\
\text { medical treatment/care, as well as other } \\
\text { relevant matters, with facility staff members. }\end{array}$ & $11(1.9)$ & $14(2.5)$ & $128(22.5)$ & $416(73.1)$ & $3.7(0.6)$ \\
\hline 36 & $\begin{array}{l}\text { We shared Mr./Ms. A's wishes about medical } \\
\text { treatment/care with the long-term care } \\
\text { insurance facilities and medical institution staff } \\
\text { with whom we work. }\end{array}$ & $25(4.4)$ & $34(6.0)$ & $126(22.1)$ & $384(67.5)$ & $3.5(0.8)$ \\
\hline 37 & $\begin{array}{l}\text { We kept a record of observations and } \\
\text { significant changes pertaining to Mr./Ms. A. } \\
\text { In making decisions about Mr./Ms. A's } \\
\text { medical treatment/care, as well as other }\end{array}$ & $6(1.1)$ & $4(0.7)$ & 85 (14.9) & $474(83.3)$ & $3.8(0.5)$ \\
\hline 38 & $\begin{array}{l}\text { matters, we took into consideration the wishes } \\
\text { Mr./Ms. A expressed regarding the final stage } \\
\text { of life and everyday routines. }\end{array}$ & $41(7.2)$ & $61(10.7)$ & $184(32.3)$ & $283(49.7)$ & $3.3(0.9)$ \\
\hline 39 & $\begin{array}{l}\text { We took Mr./Ms. A's quality of life into } \\
\text { account when making decisions about medical } \\
\text { treatment/care. }\end{array}$ & $4(0.7)$ & $17(3.0)$ & $193(33.9)$ & $355(62.4)$ & $3.6(0.6)$ \\
\hline
\end{tabular}


Table 4. Final exploratory factor analysis, Cronbach's $\alpha$, and descriptive statistics of the ACP-PI $(N=228)$.

\begin{tabular}{|c|c|c|c|c|}
\hline No. & Items & \multicolumn{3}{|c|}{ Factor Loading } \\
\hline \multicolumn{5}{|c|}{ Factor 1. Provision of information and conversation with the resident to encourage them to express their end-of-life wishes } \\
\hline 1 & $\begin{array}{l}\text { We judged from Mr./Ms. A's words, actions, and appearance whether or not they were } \\
\text { willing to talk about the final stage of life. }\end{array}$ & 0.48 & -0.09 & 0.15 \\
\hline 2 & $\begin{array}{l}\text { We informed Mr./Ms. A about the medical treatment/care available and how they } \\
\text { could spend the final stage of life, as detailed within the facility's policies. }\end{array}$ & 0.86 & -0.01 & -0.02 \\
\hline 3 & $\begin{array}{l}\text { We informed Mr./Ms. A of the significance of communicating their wishes regarding } \\
\text { the final stage of life and everyday routines to family and the facility's staff members } \\
\text { while they were still able to express wishes. }\end{array}$ & 0.86 & 0.06 & -0.08 \\
\hline 4 & $\begin{array}{l}\text { We informed Mr./Ms. A of what things they should tell family and staff members } \\
\text { while they were still able to express wishes. }\end{array}$ & 0.77 & 0.09 & -0.02 \\
\hline 5 & $\begin{array}{l}\text { We presented Mr./Ms. A with specific details about what medical treatment/care } \\
\text { options were available as they entered the final stage of life (note: this statement } \\
\text { includes cases where part-time doctors or similar staff presented the information). }\end{array}$ & 0.77 & 0.04 & -0.01 \\
\hline 7 & $\begin{array}{l}\text { We talked with Mr./Ms. A about what kind of medical treatment/care they wished for } \\
\text { at the final stage of life. }\end{array}$ & 0.93 & -0.01 & -0.05 \\
\hline 8 & We talked with Mr./Ms. A about where they would like to spend the final stages of life. & 0.87 & -0.05 & -0.06 \\
\hline 9 & $\begin{array}{l}\text { We discussed with the patient the kind of care they would like to receive to get relief } \\
\text { and comfort from distressing symptoms (e.g., breathlessness or discomfort from being } \\
\text { unable to move) at the final stage of life. }\end{array}$ & 0.79 & 0.00 & 0.05 \\
\hline 10 & $\begin{array}{l}\text { We discussed with Mr./Ms. A whether or not there were any changes in the their } \\
\text { wishes regarding medical treatment/care each time it happened. }\end{array}$ & 0.67 & 0.02 & 0.07 \\
\hline 11 & $\begin{array}{l}\text { Whenever Mr./Ms. A's condition changed, we spoke with them to establish whether } \\
\text { or not there were any changes in wishes regarding medical treatment/care. }\end{array}$ & 0.71 & 0.04 & 0.07 \\
\hline
\end{tabular}

Factor 2. Preparations in case the resident becomes unable to express their own end-of-life wish

13 We asked Mr./Ms. A to put their wishes regarding their medical treatment/care, as well as any other wishes, in writing.

$\begin{array}{ccc}0.05 & \mathbf{0 . 6 5} & -0.03 \\ -0.06 & \mathbf{0 . 7 6} & 0.01 \\ 0.04 & \mathbf{0 . 7 8} & 0.02 \\ 0.05 & \mathbf{0 . 8 8} & 0.00 \\ -0.04 & \mathbf{0 . 7 1} & 0.02\end{array}$

17 aspects after they pass away (e.g., implementing a will).

Factor 3. Devising to encourage the resident to express their wish with consideration for their dementia

19 We considered the topics of discussion regarding the final stage of Mr./Ms. A's life depending on their cognitive functioning.

The ways in which I explained the final stage of life were modified depending on

Mr./Ms. A's cognitive functions.

When discussing the final stage of life with Mr./Ms. A, we checked that they understood the content.

\begin{tabular}{rrr}
-0.07 & 0.02 & $\mathbf{0 . 8 6}$ \\
-0.01 & -0.01 & $\mathbf{0 . 9 8}$ \\
0.27 & 0.03 & $\mathbf{0 . 5 5}$ \\
\hline 0.94 & 0.86 & 0.87 \\
& $2.0(0.7)$ & \\
& $2.1(0.8)$ & \\
& $1.5(0.7)$ & \\
& $2.5(0.9)$ & \\
\hline
\end{tabular}

Note: ACP, advance care planning; ACP-PI, ACP Practice Inventory; SD, standard deviation. Italics indicate factor names. Exploratory factor analysis: promax rotation, factor loading $>0.45$. Items with factor loadings of 0.45 or higher and belonging to a factor are expressed in bold. Bartlett's sphericity test was significant $\left(\chi^{2}=3244.2\right.$, $\mathrm{df}=153, p<0.01)$, and the Kaiser-Meyer-Olkin value was $0.92 .{ }^{\dagger}$ Cronbach's $\alpha($ overall $)=0.94$. 
Table 5. The final version of Advance Care Planning Practice Inventory (ACP-PI).

\begin{tabular}{|c|c|c|c|c|c|}
\hline No. & Items & $\begin{array}{l}\text { Did Not } \\
\text { Implement }\end{array}$ & $\begin{array}{l}\text { More or Less Did } \\
\text { Not Implement }\end{array}$ & $\begin{array}{l}\text { More or Less } \\
\text { Implemented }\end{array}$ & Implemented \\
\hline 1 & $\begin{array}{l}\text { We judged from Mr./Ms. A's words, actions, and } \\
\text { appearance whether or not they were willing to } \\
\text { talk about the final stage of life. }\end{array}$ & 1 & 2 & 3 & 4 \\
\hline 2 & $\begin{array}{l}\text { We informed Mr./Ms. A about the medical } \\
\text { treatment/care available and how they could } \\
\text { spend the final stage of life, as detailed within the } \\
\text { facility's policies. }\end{array}$ & 1 & 2 & 3 & 4 \\
\hline 3 & $\begin{array}{l}\text { We informed Mr./Ms. A of the significance of } \\
\text { communicating their wishes regarding the final } \\
\text { stage of life and the everyday routines to the } \\
\text { family and the facility's staff members while they } \\
\text { were still able to express wishes. }\end{array}$ & 1 & 2 & 3 & 4 \\
\hline 4 & $\begin{array}{l}\text { We informed Mr./Ms. A of what things they } \\
\text { should tell family and staff members while they } \\
\text { were still able to express wishes. }\end{array}$ & 1 & 2 & 3 & 4 \\
\hline 5 & $\begin{array}{l}\text { We presented Mr./Ms. A with specific details } \\
\text { about what medical treatment/care options were } \\
\text { available as they entered the final stage of life } \\
\text { (note: this statement includes cases where } \\
\text { part-time doctors or similar staff presented } \\
\text { the information). }\end{array}$ & 1 & 2 & 3 & 4 \\
\hline 6 & $\begin{array}{l}\text { We talked with Mr./Ms. A about what kind of } \\
\text { medical treatment/care they wished for at the } \\
\text { final stage of life. }\end{array}$ & 1 & 2 & 3 & 4 \\
\hline 7 & $\begin{array}{l}\text { We talked with Mr./Ms. A about where they } \\
\text { would like to spend the final stages of life. }\end{array}$ & 1 & 2 & 3 & 4 \\
\hline 8 & $\begin{array}{l}\text { We discussed with the patient about the kind of } \\
\text { care they would like to receive to get relief and } \\
\text { comfort from distressing symptoms (e.g., } \\
\text { breathlessness or discomfort from being unable to } \\
\text { move) at the final stage of life. }\end{array}$ & 1 & 2 & 3 & 4 \\
\hline 9 & $\begin{array}{l}\text { We discussed with Mr./Ms. A about whether or } \\
\text { not there were any changes in the wishes of } \\
\text { Mr./Ms. A regarding medical treatment/care, } \\
\text { each time it happens. }\end{array}$ & 1 & 2 & 3 & 4 \\
\hline 10 & $\begin{array}{l}\text { Whenever Mr./Ms. A's condition changed, we } \\
\text { spoke with them to establish whether or not there } \\
\text { were any changes in wishes regarding medical } \\
\text { treatment/care. }\end{array}$ & 1 & 2 & 3 & 4 \\
\hline 11 & $\begin{array}{l}\text { We asked Mr./Ms. A to put their wishes regarding } \\
\text { their medical treatment/care, as well as any other } \\
\text { wishes, in writing. }\end{array}$ & 1 & 2 & 3 & 4 \\
\hline 12 & $\begin{array}{l}\text { At Mr./Ms. A's request, we gave a copy of the } \\
\text { written document to Mr./Ms. A stating the wishes } \\
\text { regarding medical treatment/care and } \\
\text { other matters. }\end{array}$ & 1 & 2 & 3 & 4 \\
\hline
\end{tabular}


Table 5. Cont.

\begin{tabular}{|c|c|c|c|c|c|}
\hline No. & Items & $\begin{array}{c}\text { Did Not } \\
\text { Implement }\end{array}$ & $\begin{array}{l}\text { More or Less Did } \\
\text { Not Implement }\end{array}$ & $\begin{array}{l}\text { More or Less } \\
\text { Implemented }\end{array}$ & Implemented \\
\hline 13 & $\begin{array}{l}\text { We asked Mr./Ms. A who they wished to } \\
\text { participate in discussions about medical } \\
\text { treatment/care and other matters relating to the } \\
\text { time when they would no longer be able to make } \\
\text { their own decisions. }\end{array}$ & 1 & 2 & 3 & 4 \\
\hline 14 & $\begin{array}{l}\text { We asked Mr./Ms. A whether or not they had } \\
\text { informed the person they mentioned in Point } 17 \\
\text { about their desire to have them participate in } \\
\text { such discussions. }\end{array}$ & 1 & 2 & 3 & 4 \\
\hline 15 & $\begin{array}{l}\text { We informed Mr./Ms. A about representatives } \\
\text { and/or systems that handle legal aspects after } \\
\text { they pass away (e.g., implementing a will). }\end{array}$ & 1 & 2 & 3 & 4 \\
\hline 16 & $\begin{array}{l}\text { We considered the topics of discussion regarding } \\
\text { the final stage of Mr. Ms. A's life depending on } \\
\text { their cognitive functioning. }\end{array}$ & 1 & 2 & 3 & 4 \\
\hline 17 & $\begin{array}{l}\text { The ways in which I explained the final stage of } \\
\text { life were modified depending on Mr./Ms. A's } \\
\text { cognitive functions. }\end{array}$ & 1 & 2 & 3 & 4 \\
\hline 18 & $\begin{array}{l}\text { When discussing the final stage of life with } \\
\text { Mr./Ms. A, we checked that they understood } \\
\text { the content. }\end{array}$ & 1 & 2 & 3 & 4 \\
\hline
\end{tabular}

In the Spearman's correlation analysis, the correlation coefficient between the composite score and "preparatory tasks" (sub-scale of the QOD-LTC) was $r=0.34, p<0.001$, and that of "positive attitudes toward caring for dying persons" (sub-scale of the FATCOD-B-J-S) was $\mathrm{r}=0.14, p<0.001$.

\subsection{Association between ACP-PI and QOD-LTC}

The results of Spearman's correlation analysis among the independent variables did not show any correlation coefficient $\geq 0.7$. The results of the logistic regression analysis showed a significant relationship between the QOD-LTC and the composite score, as well as each factor score of the ACP-PI, age at death, and additional end-of-life care bonus (Table 6). In model 5, where all three factors were entered simultaneously, only "provision of information and conversation with the resident to encourage them to express their end-of-life wish" was significantly associated with the QOD-LTC. 
Table 6. Logistic regression for the residents' quality of dying and related factors $(N=569)$.

\begin{tabular}{|c|c|c|c|c|c|}
\hline & $\begin{array}{c}\text { Model } 1 \\
\text { OR (95\%CI) }\end{array}$ & $\begin{array}{c}\text { Model } 2 \\
\text { OR (95\%CI) }\end{array}$ & $\begin{array}{c}\text { Model } 3 \\
\text { OR (95\%CI) }\end{array}$ & $\begin{array}{c}\text { Model } 4 \\
\text { OR (95\%CI) }\end{array}$ & $\begin{array}{c}\text { Model } 5 \\
\text { OR (95\%CI) }\end{array}$ \\
\hline \multicolumn{6}{|l|}{ Residents' characteristics } \\
\hline Female sex ${ }^{\dagger}$ & $0.90(0.57-1.42)$ & $0.97(0.61-1.54)$ & $0.91(0.58-1.42)$ & $0.87(0.55-1.35)$ & $0.93(0.59-1.48)$ \\
\hline $\begin{array}{l}\text { Length of stay } \\
\text { (years) }\end{array}$ & $0.92(0.54-1.55)$ & $0.87(0.52-1.48)$ & $0.88(0.52-1.47)$ & $0.95(0.56-1.59)$ & $0.89(0.53-1.51)$ \\
\hline Age at death (years) & $1.05(1.02-1.08)^{* *}$ & $1.05(1.02-1.08)^{* *}$ & $1.05(1.02-1.09) * *$ & $1.05(1.02-1.08)^{* *}$ & $1.05(1.02-1.08)^{* *}$ \\
\hline FAST $\S$ & $1.10(0.76-1.61)$ & $1.12(0.76-1.63)$ & $1.06(0.73-1.53)$ & $1.03(0.71-1.48)$ & $1.12(0.77-1.64)$ \\
\hline \multicolumn{6}{|c|}{ GHPWD's characteristics } \\
\hline $\begin{array}{l}\text { Number of full-time } \\
\text { nurses }\end{array}$ & $1.13(1.03-1.25) *$ & $1.13(1.02-1.24)$ * & $1.12(1.02-1.24) *$ & $1.13(1.02-1.25) *$ & $1.13(1.03-1.25)$ * \\
\hline $\begin{array}{l}\text { End-of-life care } \\
\text { bonus II }\end{array}$ & $1.64(1.12-2.38) *$ & $1.69(1.16-2.47)^{* *}$ & $1.57(1.08-2.27) *$ & $1.67(1.16-2.42) * *$ & $1.66(1.13-2.42)^{* *}$ \\
\hline \multicolumn{6}{|l|}{ ACP-PI } \\
\hline Composite score & $2.62(1.95-3.53) * * *$ & & & & \\
\hline Factor 1 & & $2.15(1.70-2.73)^{* * *}$ & & & $1.75(1.28-2.40) * * *$ \\
\hline Factor 2 & & & $2.16(1.57-2.97)^{* * *}$ & & $1.27(0.87-1.87)$ \\
\hline Factor 3 & & & & $1.65(1.35-2.01)^{* * *}$ & $1.17(0.92-1.49)$ \\
\hline
\end{tabular}

Note: OR, odds ratio; 95\%CI, 95\% confidence interval; FAST, functional assessment staging; GHPWD, group home for persons with dementia; ACP, advance care planning; ACP-PI, ACP Practice Inventory. ${ }^{*} p<0.05$, ${ }^{* *} p<0.01,{ }^{* * *} p<0.001$. Dependent variable: the QOD-LTC $-0=$ low, $1=$ high. Regarding independent variables, relevant individual and facility attributes were entered in all models; for the ACP-PI, they were entered as follows: model 1: composite score; models $2-4$ : one for each factor; model 5: all for each factor. ${ }^{\dagger} 0=$ male, $1=$ female $\ddagger 0=$ less than 1 year, $1=1$ year or more; $\S 0=$ FAST level 6 or less, $1=$ FAST level 7 ; II $0=$ none, $1=$ with bonus. Factor 1: provision of information and conversation with the resident to encourage them to express their end-of-life wishes. Factor 2: preparations in case the resident becomes unable to express their own end-of-life wishes. Factor 3: devising to encourage the resident to express their wishes with consideration for their dementia.

\section{Discussion}

This is the first study to develop an inventory for ACP-PI implementation in order to identify the factors and structure of ACP for PWD in group homes and to examine the association between inventory implementation and the residents' QOD-LTC.

\subsection{Structure of the ACP-PI for Group Homes for PWD}

In developing the ACP-PI, the validity of the items comprising the ACP-PI was verified by a literature review and expert panel using the Delphi method [19]. The factors were established in the EFA for structural validity, and CFA was used to confirm the established factors. The CFA results showed that the RMSEA did not meet the criteria, but the model's goodness of fit was improved by considering the error correlation from the modified index. The three-factor structure was deemed appropriate because a value $<0.08$ is considered "adequate" [31], and the other goodness-of-fit indices achieved the required criteria. Internal consistency was confirmed by Cronbach's alpha coefficients for the overall instrument and for each sub-factor, which were above 0.7 [29]. Thus, the inventory had sufficient reliability and validity. Further verification of reliability and validity, including test-retest reliability, should be conducted in the future.

\subsection{Description of Factors of the ACP-PI}

The factor "Provision of information and conversation with the resident to encourage them to express their end-of-life wishes" identified in this study included items on "providing information about end-of-life," as well as "discussed end-of-life care". PWD and their family members may not have the correct knowledge about the end-of-life stage [32]; hence, it is necessary to provide them with this knowledge to avoid unintended consequences. However, in group homes, there are no standard staffing requirements for medical care providers, and the number of staff is lower than in other types of long-term care insurance facilities. Therefore, it is not always possible to provide residents with optimal medical 
treatment that may be necessary when considering promoting decision making about end-of-life care within the facility [33].

The second factor, "Preparations in case the resident becomes unable to express his/her own end-of-life wish", includes writing down one's intentions and determining/informing a surrogate decision maker, like an advance directive. In previous studies, the advance directive has been considered to be a byproduct or part of the ACP $[8,34]$, and our study also confirms this.

The last factor, "Devising to encourage the resident to express his/her wish with consideration for his/her dementia", requires the inclusion of practices according to the level of cognitive functioning of PWD and provision of appropriate support for PWD to express their intentions. Because staff with less experience in dementia care might have difficulty implementing this practice, the type of training and experience required to facilitate better implementation of this factor should be further investigated.

\subsection{Association of the ACP-PI with QOD-LTC}

This study provides new insights into the effectiveness of ACP by identifying and assessing the ACP-PI's factor structure and content. The ACP-PI was associated with the QOD-LTC in both the composite score and the score for each factor. Particularly, "Provision of information and conversation with the resident to encourage them to express their endof-life wish" was more significantly related to the QOD-LTC than with other factors. The QOD-LTC includes items such as practicing end-of-life care that is unique to the individual and maintaining the individual's dignity [20], and it is presumed that the factor of ACP-PI that encourages the individual to express their intentions directly was significantly related.

There are several limitations to this study. First, the response rate was low, as with previous studies [35], and the responses may have come from facilities that are positively involved in end-of-life care. Second, we asked the care planners to respond to the quality of end-of-life care by recalling a patient who had died in the facility, which is not the same as the quality of end-of-life care as judged by the PWD or their family. Third, while the definition of ACP [8] includes patients, family members, and facility staff, items related to family and staff were eliminated from distribution during the course of the analysis. Finally, since this study only included group homes that provide end-of-life care, it is necessary to examine the applicability of our findings to other similar facilities.

\section{Conclusions}

This study involved developing an inventory to assess the relationship between ACPPI implementation and residents' quality of dying in PWD group homes. The inventory allows for a structured view of ACP, unlike the assessment of ACP that has been done in previous studies. The ACP-PI may be applicable to intervention studies involving educational programs to improve the quality of dying and decision support, as well as to studies in settings other than group homes.

Author Contributions: Conceptualization: S.T., Y.O., and Y.Y.; methodology: S.T., Y.O., and M.I.; software: S.T.; validation: S.T., Y.O., Y.Y., and M.I.; formal analysis: S.T., Y.O., and M.I.; Investigation, Resources, and data curation: S.T. writing—original draft preparation: S.T.; writing-review and editing: Y.O., M.I., and Y.Y.; visualization, supervision, project administration, and funding acquisition: S.T. All authors have read and agreed to the published version of the manuscript.

Funding: This study was funded by a 2019 research grant from the Policy-Based Medical Services Foundation and the Univers Foundation (19-01-182). The principal recipient for all the grants was Seira Takada.

Institutional Review Board Statement: The study was conducted according to the guidelines of the Declaration of Helsinki and approved by the Medical Research Ethics Committee of Tokyo Medical and Dental University (protocol code M2019-064; date of approval, 23 July 2019).

Informed Consent Statement: Informed consent was obtained from all participants involved in the study. 
Data Availability Statement: Data sharing is not applicable to this article because we have not obtained approval of the participants or the Ethics Committee to release the data.

Acknowledgments: The authors thank all those who participated in this study.

Conflicts of Interest: The authors declare no conflict of interest.

\section{References}

1. Alzheimer's Disease International. World Alzheimer Report 2019-Attitudes to Dementia; Alzheimer's Disease International: London, UK, 2019. Available online: https:/ / www.alzint.org/resource/world-alzheimer-report-2019/ (accessed on 10 March 2021).

2. Cabinet Office of Japan. White Paper on the Aging Society (Summary Version) Health and Welfare of the Elderly; Cabinet Office of Japan: Tokyo, Japan, 2016; p. FY2016. Available online: https://www8.cao.go.jp/kourei/whitepaper/w-2016/html/gaiyou/s1_2_3 .html (accessed on 10 March 2021).

3. International Longevity Center, Japan. Overview of the Revision of the Long-Term Care Insurance System-Amendment of the Long-Term Care Insurance Law and Long-Term Care Fee; Ministry of Health, Labour and Welfare: Tokyo, Japan, 2008. Available online: http:/ / www.ilcjapan.org/linksE/doc/Overview_of_the_Revision_of_LTCI.pdf (accessed on 10 March 2021).

4. Social Security Council. Overview of Group Homes for Person with Dementia; Ministry of Health, Labour and Welfare: Tokyo, Japan, 2009. Available online: https://www.mhlw.go.jp/shingi/2009/05/dl/s0521-3c_0018.pdf (accessed on 10 March 2021).

5. Social Security Council, Subcommittee on Nursing Care Benefits. Support for Dementia; Ministry of Health, Labour and Welfare: Tokyo, Japan, 2011. Available online: https://www.mhlw.go.jp/stf/shingi/2r9852000001va0b-att/2r9852000001va2g.pdf (accessed on 10 March 2021).

6. National Association of Group Homes for Dementia. Research Project on End-of-Life Care in Group Homes for Dementia; National Association of Group Homes for Dementia: Tokyo, Japan, 2007. Available online: https://www.ghkyo.or.jp/news/wp-content/ uploads/2017/02/chousakenkyuujigyouhoukoku-02.pdf (accessed on 10 March 2021).

7. Ogawara, H.; Fukahori, H.; Hirooka, K.; Miyashita, M. Quality evaluation and improvement for end-of-life care toward residents in long term care facilities in Japan: A Literature Review. Palliat. Care Res. 2016, 11, 401-412. [CrossRef]

8. $\quad$ Sudore, R.L.; Lum, H.D.; You, J.J.; Hanson, L.C.; Meier, D.E.; Pantilat, S.Z.; Matlock, D.D.; Rietjens, J.A.C.; Korfage, I.J.; Ritchie, C.S.; et al. Defining advance care planning for adults: A consensus definition from a multidisciplinary Delphi panel. J. Pain Symptom Manag. 2017, 53, 821-832.e1. [CrossRef]

9. Dixon, J.; Karagiannidou, M.; Knapp, M. The effectiveness of advance care planning in improving end-of-life outcomes for people with dementia and their carers: A systematic review and critical discussion. J. Pain Symptom Manag. 2018, 55, 132-150.e1. [CrossRef]

10. Pivodic, L.; Smets, T.; Van den Noortgate, N.; Onwuteaka-Philipsen, B.D.; Engels, Y.; Szczerbińska, K.; Finne-Soveri, H.; Froggatt, K.; Gambassi, G.; Deliens, L.; et al. Quality of dying and quality of end-of-life care of nursing home residents in six countries: An epidemiological study. Palliat. Med. 2018, 32, 1584-1595. [CrossRef]

11. Garden, G.; Green, S.; Pieniak, S.; Gladman, J. The Bromhead Care Home Service: The impact of a service for care home residents with dementia on hospital admission and dying in preferred place of care. Clin. Med. 2016, 16, 114-118. [CrossRef]

12. Brazil, K.; Carter, G.; Cardwell, C.; Clarke, M.; Hudson, P.; Froggatt, K.; McLaughlin, D.; Passmore, P.; Kernohan, W.G Effectiveness of advance care planning with family carers in dementia nursing homes: A paired cluster randomized controlled trial. Palliat. Med. 2018, 32, 603-612. [CrossRef]

13. Detering, K.M.; Hancock, A.D.; Reade, M.C.; Silvester, W. The impact of advance care planning on end of life care in elderly patients: Randomised controlled trial. BMJ 2010, 340, c1345. [CrossRef]

14. Ministry of Health, Labour and Welfare. Search for Nursing Care Facilities and Living-Related Information-Nursing Care Service Information Publication System; Ministry of Health, Labour and Welfare: Tokyo, Japan, 2021. Available online: https://www. kaigokensaku.mhlw.go.jp/ (accessed on 10 March 2021).

15. Mokkink, L.B.; Terwee, C.B.; Patrick, D.L.; Alonso, J.; Stratford, P.W.; Knol, D.L.; Bouter, L.M.; de Vet, H.C.W. COSMIN Checklist Manual; University Medical Center: Amsterdam, The Netherlands, 2012.

16. Peters, M.D.; Godfrey, C.M.; Khalil, H.; McInerney, P.; Parker, D.; Soares, C.B. Guidance for conducting systematic scoping reviews. Int. J. Evid. Based Healthc. 2015, 13, 141-146. [CrossRef]

17. Japan Medical Association. Guidelines for Medical Care and Treatment in the End-of-Life Stage; Japan Medical Association: Tokyo, Japan, 2018. Available online: https://www.med.or.jp/dl-med/doctor/r0205_acp_guideline.pdf (accessed on 10 December 2021).

18. National Health Service. Advance Care Planning: A Guide for Health and Social Care Staff; National Health Service: London, UK, 2007. Available online: https:/ / www.stlukes-hospice.org.uk/wp-content/uploads/2017/06/ACP-Guide-for-Health-and-SocialCare-Staff-.pdf (accessed on 12 December 2021).

19. Fitch, K.; Bernstein, S.J.; Aguilar, M.D.; Burnand, B.; LaCalle, J.R.; Lazaro, P.; van het Loo, M.; McDonnell, J.; Vader, J.; Kahan, J.P. The RAND/UCLA Appropriateness Method User's Manual; RAND Corporation: Santa Monica, CA, USA, 2001. Available online: https:/ / www.rand.org/pubs/monograph_reports/MR1269.html (accessed on 16 December 2021).

20. Munn, J.C.; Zimmerman, S.; Hanson, L.C.; Williams, C.S.; Sloane, P.D.; Clipp, E.C.; Tulsky, J.A.; Steinhauser, K.E. Measuring the quality of dying in long-term care. J. Am. Geriatr. Soc. 2007, 55, 1371-1379. [CrossRef] 
21. Sclan, S.G.; Reisberg, B. Functional Assessment Staging (FAST) in Alzheimer's disease: Reliability, validity, and ordinality. Int. Psychogeriatr. 1992, 4 (Suppl. S1), 55-69. [CrossRef] [PubMed]

22. Tay, R.Y.; Hum, A.Y.M.; Ali, N.B.; Leong, I.Y.O.; Wu, H.Y.; Chin, J.J.; Lee, A.O.K.; Koh, M.Y.H. Comfort and satisfaction with care of home-dwelling dementia patients at the end of life. J. Pain Symptom Manag. 2020, 59, 1019-1032.e1. [CrossRef] [PubMed]

23. Social Security Council. [Theme 1] End-of-Life Care, Reference Materials; Ministry of Health, Labour and Welfare: Tokyo, Japan, 2017. Available online: https:/ / www.mhlw.go.jp/file/05-Shingikai-12404000-Hokenkyoku-Iryouka/0000156003.pdf (accessed on 10 March 2021).

24. Frommelt, K.H. The effects of death education on nurses' attitudes toward caring for terminally ill persons and their families. Am. J. Hosp. Palliat. Care 1991, 8, 37-43. [CrossRef] [PubMed]

25. Nakai, Y.; Miyashita, M.; Sasahara, T.; Koyama, Y.; Shimizu, Y.; Kawa, M. Factor structure and reliability of the Japanese version of the Frommelt Attitudes Toward Care of the Dying Scale (FATCOD-B-J). Jpn. J. Cancer Care 2006, 11, 723-729. [CrossRef]

26. Moshagen, M.; Musch, J. Sample size requirements of the robust weighted least squares estimator. Methodology 2014, 10, 60-70. [CrossRef]

27. Hu, L.T.; Bentler, P.M. Cutoff Criteria for fit indexes in covariance structure analysis: Conventional criteria versus new alternatives. Struct. Equ. Model. Multidiscip. J. 1999, 6, 1-55. [CrossRef]

28. MacCallum, R.C.; Browne, M.W.; Sugawara, H.M. Power analysis and determination of sample size for covariance structure modeling. Psychol. Methods 1996, 1, 130-149. [CrossRef]

29. Terwee, C.B.; Bot, S.D.; de Boer, M.R.; van der Windt, D.A.; Knol, D.L.; Dekker, J.; Bouter, L.M.; de Vet, H.C. Quality criteria were proposed for measurement properties of health status questionnaires. J. Clin. Epidemiol. 2007, 60, 34-42. [CrossRef] [PubMed]

30. Dormann, C.F.; Elith, J.; Bacher, S.; Buchmann, C.; Carl, G.; Carré, G.; Marquéz, J.R.G.; Gruber, B.; Lafourcade, B.; Leitão, P.J.; et al Collinearity: A review of methods to deal with it and a simulation study evaluating their performance. Ecography 2013, 36, 27-46. [CrossRef]

31. Brown, T.A.; Little, T.D. Confirmatory Factor Analysis for Applied Research, 2nd ed.; Guilford Press: New York, NY, USA, 2015.

32. Lüdecke, D.; von dem Knesebeck, O.; Kofahl, C. Public knowledge about dementia in Germany-Results of a population survey. Int. J. Public Health 2016, 61, 9-16. [CrossRef]

33. Hirakawa, Y.; Masuda, Y.; Uemura, K.; Kuzuya, M.; Kimata, T.; Iguchi, A. End-of-life care at group homes for patients with dementia in Japan. Findings from an analysis of policy-related differences. Arch. Gerontol. Geriatr. 2006, 42, 233-245. [CrossRef]

34. Sudore, R.L.; Boscardin, J.; Feuz, M.A.; McMahan, R.D.; Katen, M.T.; Barnes, D.E. Effect of the PREPARE website vs. an easy-to-read advance directive on advance care planning documentation and engagement among veterans: A randomized clinical trial. JAMA Intern. Med. 2017, 177, 1102-1109. [CrossRef] [PubMed]

35. Katahira, N.; Tsukasaki, K. Nursing care in multifunctional small group homes providing day, visiting and overnight services for older people living at home. Int. J. Nurs. Pract. 2016, 22, 605-615. [CrossRef] [PubMed] 